\title{
Stability of Phases in the Si-C-N-O System
}

\author{
HARUE WADA, ${ }^{\star}$ MING-JONG WANG, ${ }^{*}$ and TSENG-YING TIEN ${ }^{\star}$ \\ Department of Materials Science and Engineering, University of Michigan, Ann Arbor, Michigan 48109
}

\begin{abstract}
The stability of the phases in equilibrium is calculated for the Si-C-N-O system in order to analyze and predict the reactions in ceramic whisker formation and sintering of silicon nitride composites. Equilibria among $\mathrm{SiC}, \mathrm{Si}_{3} \mathrm{~N}_{4}, \mathrm{Si}_{2} \mathrm{~N}_{2} \mathrm{O}, \mathrm{SiO}_{2}, \mathrm{Si}$, and the gas phase are evaluated at different carbon activities, nitrogen pressures, and temperatures. Phase stability diagrams are constructed as a function of nitrogen and oxygen pressures for two levels of carbon activity. Silicon nitride becomes a stable phase with increasing nitrogen pressure or decreasing carbon activity and temperature, whereas silicon carbide becomes a dominant phase at lower nitrogen pressures or at higher temperatures when carbon activity is unity. The maximum sintering temperature of the $\mathrm{SiC} / \mathrm{Si}_{3} \mathrm{~N}_{4}$ composite is higher with an elevated nitrogen pressure or a reduced carbon activity.
\end{abstract}

\section{Introduction}

B OTH silicon nitride and silicon carbide are advanced engineering materials that are expected to be used in a wide range of applications. The stability of the phases in the $\mathrm{Si}-\mathrm{C}-\mathrm{N}-\mathrm{O}$ system, including the gas phase, is calculated to predict and analyze the reactions in the formation and sintering of silicon nitride and silicon carbide. Since the sintering or the formation of powders and whiskers of silicon nitride is usually performed with either a graphite resistance furnace or a nongraphite furnace under a nitrogen/argon atmosphere, carbon activity and nitrogen pressure are the main variables in this calculation. Other important factors are oxygen partial pressure and temperature. Temperature is limited to a practical range which is commonly applied for sintering. The oxygen partial pressure in the gas phase controls the formation of certain phases such as silicon oxynitride and silica. The equilibrium oxygen partial pressure and the partial pressure of silicon monoxide $(\mathrm{SiO})$ - which controls the high-temperature decomposition of silicon nitride — can be determined by thermodynamic calculations.

Phase equilibria in the system based on silicon nitride have been calculated by Weiss et $a l^{1,2}$ The Si-N-O, Si-C-O, Si-C-N, and $\mathrm{Si}-\mathrm{C}-\mathrm{N}-\mathrm{O}$ systems have been calculated by the Lukas program $^{3}$ and the Eriksson program. ${ }^{4}$ These calculations cover a high-temperature range and a wide range of compositions. The gas-phase compositions and the phases in equilibrium with the gases are summarized in Table 3 of Ref. 1. Weiss et al. did not include carbon activity as a variable in their calculations. Therefore, the equilibrium gas compositions in the systems without graphite should be considered separately from those calculated for a carbon activity of unity.

To clearly demonstrate a relationship between the solid and gas phases, the solid phase stability is calculated as a function of gas composition and pressure at known temperatures and carbon activities.

\section{Stability of Phases}

\section{(1) Phases in Equilibrium}

The equilibrium phases in the system are $\beta-\mathrm{Si}_{3} \mathrm{~N}_{4}, \mathrm{Si}_{2} \mathrm{~N}_{2} \mathrm{O}$, $\beta$-SiC, $\mathrm{SiO}_{2}$ (crystobalite), $\mathrm{Si}, \mathrm{C}$, and a gas phase. The main components of the gas phase are $\mathrm{N}_{2}, \mathrm{O}_{2}, \mathrm{SiO}$, and $\mathrm{CO} / \mathrm{CO}_{2}$.

Manuscript No. 199373. Received December 31, 1987; approved March 28, 1988

Supported by the National Science Foundation under Grant No. MSM-8700568. ${ }^{*}$ Member, the American Ceramic Society.
Two carbon activity levels, $a_{\mathrm{C}}=1$ and $10^{-4}$, which are referred to solid graphite as a standard state, are used for the calculation. The temperature is from 1573 to $2073 \mathrm{~K}$. This is a fairly close approximation of the actual experimental conditions; for example, when a graphite crucible or furnace is used for $\mathrm{Si}_{3} \mathrm{~N}_{4}$ sintering, the carbon activity would be unity or very close to unity, whereas it would be very low in an elevated pressure, nongraphite furnace.

\section{(2) Three-Phase Equilibria}

Equilibrium between two solid phases and a gas phase is calculated first. For instance, equilibrium between $\mathrm{Si}_{3} \mathrm{~N}_{4}$ and $\mathrm{SiC}$ is expressed as follows for the present temperature range:

$$
\beta-\mathrm{Si}_{3} \mathrm{~N}_{4}+3 \mathrm{C}(s)=3 \beta-\mathrm{SiC}+2 \mathrm{~N}_{2}(g)
$$

The ratio of the activities of $\mathrm{Si}_{3} \mathrm{~N}_{4}$ and $\mathrm{SiC}$, which are referred to solid $\mathrm{Si}_{3} \mathrm{~N}_{4}$ and $\mathrm{SiC}$, respectively, is written as

$$
\log \left(a_{\mathrm{SiC}}^{3} / a_{\mathrm{Si}_{3} \mathrm{~N}_{4}}\right)=\log K_{1}+3 \log a_{\mathrm{C}}-2 \log p_{\mathrm{N}_{2}}
$$

where $K_{1}$ is the equilibrium constant of Eq. (1). Since $\mathrm{Si}_{3} \mathrm{~N}_{4}$ and $\mathrm{SiC}$ form almost no solid solution, their activities are either unity or less than unity - the activity of unity showing that the species exists as a solid phase, whereas an activity of less than unity shows nonexistence of the solid phase of that species. There are three possibilities for Eq. (I): If $\log \left(a_{\mathrm{SiC}}^{3} / a_{\mathrm{Si}_{3} \mathrm{~N}_{4}}\right)=0$, then $a_{\mathrm{SiC}}=a_{\mathrm{Si}_{3} \mathrm{~N}_{4}}=1$; if $\log \left(a_{\mathrm{SiC}}^{3} / a_{\mathrm{Si}_{3} \mathrm{~N}_{4}}\right)>0$, then $a_{\mathrm{SiC}}=1$ and $a_{\mathrm{Si}_{3} \mathrm{~N}_{4}}<1$; and if $\log \left(a_{\mathrm{SiC}}^{3} / a_{\mathrm{Si}_{3} \mathrm{~N}_{4}}\right)<0$, then $a_{\mathrm{SiC}}<1$ and $a_{\mathrm{Si}_{3} \mathrm{~N}_{4}}=1$. In the first case, the $\mathrm{Si}_{3} \mathrm{~N}_{4}$ and $\mathrm{SiC}$ phases coexist, whereas $\mathrm{SiC}$ is the stable phase in the second case and $\mathrm{Si}_{3} \mathrm{~N}_{4}$ is the stable phase in the third case.

Equation (I) is calculated as a function of temperature for $a_{\mathrm{C}}=1$ and $p_{\mathrm{N}_{2}}=1$ and $10 \mathrm{~atm}(0.10$ and $1.01 \mathrm{MPa})$ as shown in Fig. 1. At $p_{\mathrm{N}_{2}}=1 \mathrm{~atm}(0.10 \mathrm{MPa}), \mathrm{Si}_{3} \mathrm{~N}_{4}$ and $\mathrm{SiC}$ are in equilibrium at $1647 \mathrm{~K}$. SiC is stable at higher temperatures, and $\mathrm{Si}_{3} \mathrm{~N}_{4}$ is stable at lower temperatures, whereas the temperature for equilibrium between the two phases moves upward to $1809 \mathrm{~K}$ when the nitrogen pressure is increased to $10 \mathrm{~atm}(1.01 \mathrm{MPa})$. This information can be applied as a guideline to the sintering of $\mathrm{Si}_{3} \mathrm{~N}_{4}$ ceramic or $\mathrm{SiC} / \mathrm{Si}_{3} \mathrm{~N}_{4}$ composite.

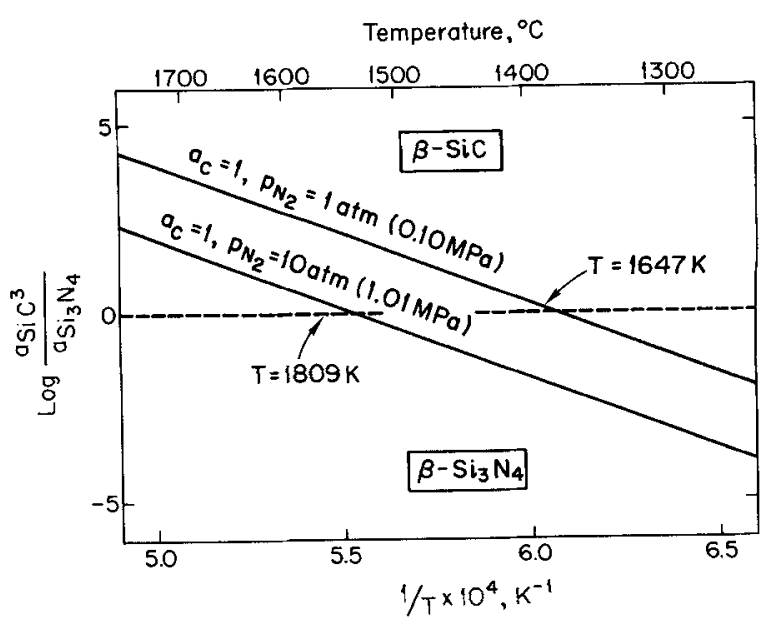

Fig. 1. Equilibrium between $\beta-\mathrm{SiC}$ and $\beta-\mathrm{Si}_{3} \mathrm{~N}_{4}$ at $a_{\mathrm{C}}=1$ with $p_{\mathrm{N}_{2}}=1$ and $10 \mathrm{~atm}(0.10$ and $1.01 \mathrm{MPa})$. 
Table I. Equilibrium Reactions in Si-C-N-O System

\begin{tabular}{ll}
\hline \multicolumn{1}{c}{ Reaction } \\
\hline$(1)$ & $\beta-\mathrm{Si}_{3} \mathrm{~N}_{4}+3 \mathrm{C}(s)=3 \beta-\mathrm{SiC}+2 \mathrm{~N}_{2}(g)$ \\
$(2)$ & $4 \beta-\mathrm{Si}_{3} \mathrm{~N}_{4}+3 \mathrm{O}_{2}(g)=6 \mathrm{Si}_{2} \mathrm{~N}_{2} \mathrm{O}(s)+2 \mathrm{~N}_{2}(g)$ \\
$(3)$ & $\beta-\mathrm{Si}_{3} \mathrm{~N}_{4}+3 \mathrm{O}_{2}(g)=3 \mathrm{SiO}_{2}(c)+2 \mathrm{~N}_{2}(g)$ \\
$(4)$ & $2 \mathrm{Si}_{2} \mathrm{~N}_{2} \mathrm{O}(s)+4 \mathrm{C}(s)=4 \beta-\mathrm{SiC}+\mathrm{O}_{2}(g)+2 \mathrm{~N}_{2}(g)$ \\
$(5)$ & $2 \mathrm{Si}_{2} \mathrm{~N}_{2} \mathrm{O}(s)+3 \mathrm{O}_{2}(g)=4 \mathrm{SiO}_{2}(c)+2 \mathrm{~N}_{2}(g)$ \\
$(6)$ & $\mathrm{SiO}_{2}(c)+\mathrm{C}(s)=\beta-\mathrm{SiC}+\mathrm{O}_{2}(g)$ \\
$(7)$ & $3 \mathrm{Si}(l)$ or $(s)+2 \mathrm{~N}_{2}(g)=\beta-\mathrm{Si}_{3} \mathrm{~N}_{4}$ \\
$(8)$ & $4 \mathrm{Si}(l)$ or $(s)+2 \mathrm{~N}_{2}(g)+\mathrm{O}_{2}(g)=2 \mathrm{Si}_{2} \mathrm{~N}_{2} \mathrm{O}(s)$ \\
$(9)$ & $\mathrm{Si}(l)$ or $(s)+\mathrm{O}_{2}(g)=\mathrm{SiO}_{2}(c)$ \\
\hline
\end{tabular}

Table II. Standard Free Energies of Formation of Condensed Phases

\begin{tabular}{llc}
\hline \multicolumn{1}{c}{ Species } & \multicolumn{1}{c}{$\Delta_{f} G^{\circ}(\mathrm{kJ} / \mathrm{mol})^{*}$} & Reference \\
\hline$\beta-\mathrm{Si}_{3} \mathrm{~N}_{4}$ & $-925.2+0.450 T$ & 6 \\
$\mathrm{Si}_{2} \mathrm{~N}_{2} \mathrm{O}$ & $-658.3+0131 T$ & 6 \\
$\beta-\mathrm{SiC}_{\mathrm{C}}$ & $-72.832+0.007 T$ & 5 \\
$\mathrm{SiO}(c)$ & $-900.384+0.171 T$ & 5 \\
$\mathrm{Si}(l)$ & $-42.825+0.0647 T-0.24 \times 10^{-4} T^{2}$ & 5 \\
\hline
\end{tabular}

${ }^{*}$ Standard states are $\mathrm{Si}(s), \mathrm{C}(s), p_{\mathrm{N}_{2}}=1 \mathrm{~atm}(0.10 \mathrm{MPa})$, and $p_{\mathrm{O}_{2}}=1 \mathrm{~atm}$ $(0.10 \mathrm{MPa})$.

Table III. Invariant Points at Given $a_{\mathrm{C}}$ and Temperature

\begin{tabular}{|c|c|c|c|}
\hline$a_{\mathrm{C}}$ & $T(\mathrm{~K})$ & $\begin{array}{c}\mathrm{Si}_{3} \mathrm{~N}_{4} / \mathrm{Si}_{2} \mathrm{~N}_{2} \mathrm{O} / \mathrm{SiC} \\
(\mathrm{atm}(\mathrm{MPa})) \\
\end{array}$ & $\begin{array}{c}\mathrm{SiO}_{2} / \mathrm{Si}_{2} \mathrm{~N}_{2} \mathrm{O} / \mathrm{SiC} \\
(\operatorname{atm}(\mathrm{MPa})) \\
\end{array}$ \\
\hline 1 & 1673 & $\begin{array}{l}p_{\mathrm{N}_{2}}=10^{0.17}\left(10^{-0.82}\right) \\
p_{\mathrm{O}_{2}}=10^{-20.13}\left(10^{-21.12}\right) \\
p_{\mathrm{N}_{2}}=10^{1.85}\left(10^{0.86}\right) \\
p_{\mathrm{O} 2}=10^{-18.62}\left(10^{-19.61}\right)\end{array}$ & $\begin{array}{l}p_{\mathrm{N}_{2}}=10^{-1.26}\left(10^{-2.25}\right) \\
p_{\mathrm{O}_{2}}=10^{-17.27}\left(10^{-18.26}\right) \\
p_{\mathrm{N}_{2}}=10^{-0.79}\left(10^{-1.78}\right) \\
p_{\mathrm{O}_{2}}=10^{-13.34}\left(10^{-14.33}\right)\end{array}$ \\
\hline$a_{\mathrm{C}}$ & $T(\mathrm{~K})$ & $\begin{array}{c}\mathrm{Si}_{3} \mathrm{~N}_{4} / \mathrm{Si}_{2} \mathrm{~N}_{2} \mathrm{O} / \mathrm{Si}(s) \text { or }(l) \\
(\operatorname{atm}(\mathrm{MPa}))\end{array}$ & $\begin{array}{c}\mathrm{SiO}_{2} / \mathrm{Si}_{2} \mathrm{~N}_{2} \mathrm{O} / \mathrm{Si}(s) \text { or }(l) \\
(\mathrm{atm}(\mathrm{MPa}))\end{array}$ \\
\hline $10^{-4}$ & 1973 & $\begin{array}{l}p_{\mathrm{N}_{2}}=10^{-2.69}\left(10^{-3.68}\right) \\
p_{\mathrm{O}_{2}}=10^{-22.04}\left(10^{-23.03}\right) \\
p_{\mathrm{N}_{2}}=10^{-0.15}\left(10^{-1.14}\right) \\
p_{\mathrm{O}_{2}}=10^{-19.75}\left(10^{-20.74}\right)\end{array}$ & $\begin{array}{l}p_{\mathrm{N}_{2}}=10^{-4.12}\left(10^{-5.11}\right) \\
p_{\mathrm{O}_{2}}=10^{-19.18}\left(10^{-20.17}\right) \\
p_{\mathrm{N}_{2}}=10^{-2.65}\left(10^{-3.64}\right) \\
p_{\mathrm{O}_{2}}=10^{-14.58}\left(10^{-15.57}\right)\end{array}$ \\
\hline
\end{tabular}

Other equilibria, such as $\mathrm{Si}_{3} \mathrm{~N}_{4} / \mathrm{Si}_{2} \mathrm{~N}_{2} \mathrm{O}, \mathrm{Si}_{3} \mathrm{~N}_{4} / \mathrm{SiO}_{2}$, $\mathrm{Si}_{2} \mathrm{~N}_{2} \mathrm{O} / \mathrm{SiO}_{2}, \mathrm{Si}_{2} \mathrm{~N}_{2} \mathrm{O} / \mathrm{SiC}, \mathrm{SiC} / \mathrm{SiO}_{2}, \mathrm{Si} / \mathrm{Si}_{3} \mathrm{~N}_{4}, \mathrm{Si}_{2} \mathrm{Si}_{2} \mathrm{~N}_{2} \mathrm{O}$, and $\mathrm{Si} / \mathrm{SiO}_{2}$ are calculated by the same principle. The equilibrium reactions in the Si-C-N-O system in the temperature range concerned in this study are summarized in Table I. The standard free energies of formation are obtained mainly from JANAF Tables. ${ }^{5}$ The free energies of formation of $\beta-\mathrm{Si}_{3} \mathrm{~N}_{4}$ and $\mathrm{Si}_{2} \mathrm{~N}_{2} \mathrm{O}$ are not listed in JANAF. These two phases are important phases in the Si-C-N-O system and their free energies should be consistent with each other. Two values are accepted from Hendry. ${ }^{6}$ The standard free energies of formation of the solid phases are summarized in Table II.

\section{(3) Four-Phase Equilibria}

When three solid phases and a gas phase are in equilibrium, the number of degrees of freedom determined from the phase rule is two. Combining the equations shown in Table II, phase stability is calculated at $a_{\mathrm{C}}=1$ and $10^{-4}$ and at temperatures 1673 and $1973 \mathrm{~K}$. For instance, the $\mathrm{Si}_{3} \mathrm{~N}_{4} / \mathrm{Si}_{2} \mathrm{~N}_{2} \mathrm{O} / \mathrm{SiC} /$ gas-phase equi- librium is calculated as follows from reactions (1) and (2) in Table I:

$$
\begin{aligned}
\log K_{1}+3 \log a_{\mathrm{C}}-2 \log p_{\mathrm{N}_{2}} & =-36909.385 / T \\
+22.406+3 \log a_{\mathrm{C}}-2 \log p_{\mathrm{N}_{2}} & =0 \\
\log K_{2}-2 \log p_{\mathrm{N}_{2}}+3 \log p_{\mathrm{O}_{2}} & =13004.648 / T \\
+52.959-2 \log p_{\mathrm{N}_{2}}+3 \log p_{\mathrm{O}_{2}} & =0
\end{aligned}
$$

At known $a_{\mathrm{C}}$ and temperature, the oxygen and nitrogen pressures are calculated for this invariant point. Other invariant points are also calculated as summarized in Table III.

Examples of calculated stability diagrams are shown in Figs. 2 and 3 . Figure 2 shows the stability diagram for $a_{\mathrm{C}}=1$ and $T=1673$ and $1973 \mathrm{~K}$, which are shown with solid and dashed lines, respectively. The most significant feature of the diagram is the effect of nitrogen pressure and temperature on the phase sta-

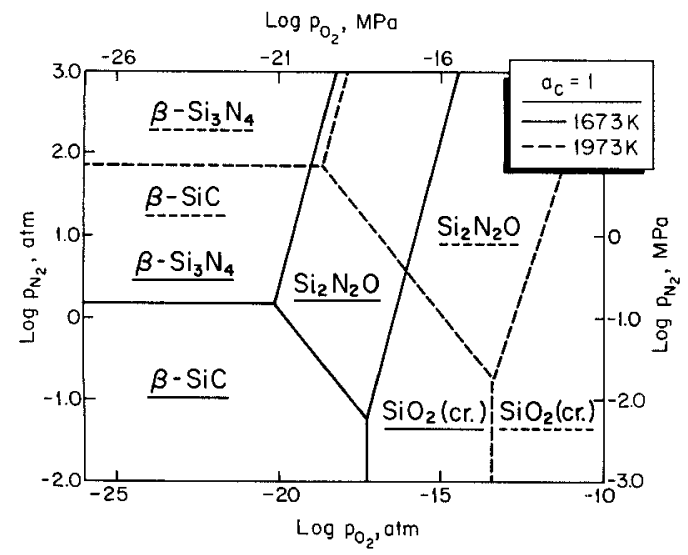

Fig. 2. Phase stability diagram as a function of partial pressures of nitrogen and oxygen at $a_{C}=1, T=1673$ and $1973 \mathrm{~K}$.

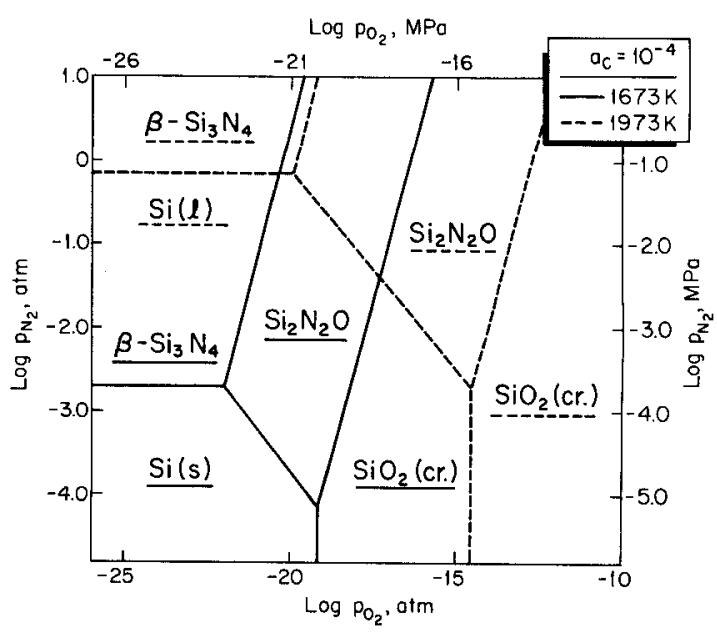

Fig. 3. Phase stability diagram as a function of partial pressures of nitrogen and oxygen at $a_{\mathrm{C}}=10^{-4}, T=1673$ and $1973 \mathrm{~K}$. 


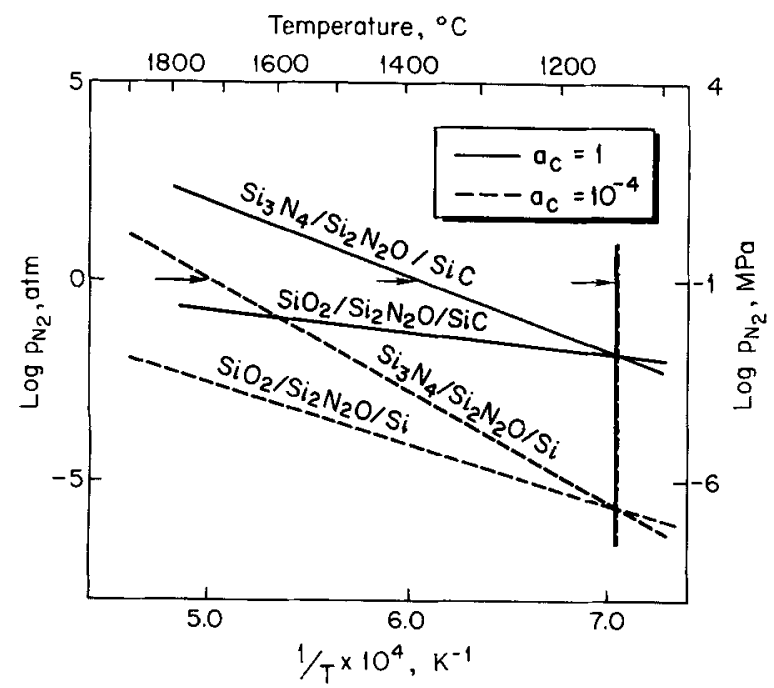

Fig. 4. Changes in equilibrium nitrogen partial pressure at invariant points as a function of temperature at $a_{C}=1$ and $10^{-4}$.

bility, especially at the two invariant points where the effects can be seen simultaneously. A large increase in the nitrogen pressure is required to make $\mathrm{Si}_{3} \mathrm{~N}_{4}$ the stable phase at $1973 \mathrm{~K}$, and avoiding $\mathrm{Si}_{2} \mathrm{~N}_{2} \mathrm{O}$ phase formation is still difficult with increasing temperature. This effect of temperature is shown more dramatically in Fig. 3 when the carbon activity is reduced to $a_{\mathrm{c}}=10^{-4}$. These stability diagrams can be a valuable guide in various fields. One such field is ceramics sintering, which we will address in a later section.

\section{(4) Gas Phase}

The composition and pressure in the gas phase affects the stability of solid phases, as expected from Table I. Changes in the nitrogen and oxygen pressures at both invariant points for the $\mathrm{Si}_{3} \mathrm{~N}_{4} / \mathrm{Si}_{2} \mathrm{~N}_{2} \mathrm{O} / \mathrm{SiC}$ and $\mathrm{SiO}_{2} / \mathrm{Si}_{2} \mathrm{~N}_{2} \mathrm{O} / \mathrm{SiC}$ or $\mathrm{Si}_{3} \mathrm{~N}_{4} / \mathrm{Si}_{2} \mathrm{~N}_{2} \mathrm{O} / \mathrm{Si}$ and $\mathrm{SiO}_{2} / \mathrm{Si}_{2} \mathrm{~N}_{2} \mathrm{O} / \mathrm{Si}$ equilibria are shown as a function of temperature in Figs. 4 and 5, respectively. Both $\mathrm{Si}_{3} \mathrm{~N}_{4} / \mathrm{Si}_{2} \mathrm{~N}_{2} \mathrm{O} / \mathrm{SiC}$ and $\mathrm{SiO}_{2} / \mathrm{Si}_{2} \mathrm{~N}_{2} \mathrm{O} / \mathrm{SiC}$ or $\mathrm{Si}_{3} \mathrm{~N}_{4} / \mathrm{Si}_{2} \mathrm{~N}_{2} \mathrm{O} / \mathrm{Si}$ and $\mathrm{SiO}_{2} / \mathrm{Si}_{2} \mathrm{~N}_{2} \mathrm{O} / \mathrm{Si}$ equilibria reach equilibrium with the same gas composition at $1417.8 \mathrm{~K}$, as shown in Figs. 4 and 5.

The stability diagram at $1417.8 \mathrm{~K}$ is shown in Fig. 6 . The phase stability is governed by the following reaction:

$$
\mathrm{Si}_{3} \mathrm{~N}_{4}+\mathrm{SiO}_{2}=2 \mathrm{Si}_{2} \mathrm{~N}_{2} \mathrm{O}
$$

Hence, the silicon oxynitride $\left(\mathrm{Si}_{2} \mathrm{~N}_{2} \mathrm{O}\right)$ phase is present on the same line at both carbon activities regardless of nitrogen and oxygen pressures until the $\mathrm{SiC}$ or $\mathrm{Si}(s)$ phase appears at lower nitrogen pressures for $a_{\mathrm{C}}=1$ and $10^{-4}$, respectively.

All $\mathrm{SiC}, \mathrm{Si}_{3} \mathrm{~N}_{4}$, and $\mathrm{Si}_{2} \mathrm{~N}_{2} \mathrm{O}$ formations from $\mathrm{SiO}_{2}$ occur via intermediate $\mathrm{SiO}(g)$ formation, and a high-temperature decomposition of $\mathrm{Si}_{3} \mathrm{~N}_{4}$ is also related to $\mathrm{SiO}(g)$ as

$$
\begin{aligned}
& \mathrm{SiO}_{2}(s)+\mathrm{C}(s) \rightarrow \mathrm{SiO}(g)+\mathrm{CO}(g) \\
& \mathrm{SiO}(g)+3 \mathrm{CO}(g) \rightarrow \mathrm{SiC}(s)+2 \mathrm{CO}_{2}(g) \\
& 3 \mathrm{SiO}(g)+3 \mathrm{CO}(g)+2 \mathrm{~N}_{2}(g) \rightarrow \mathrm{Si}_{3} \mathrm{~N}_{4}(s)+3 \mathrm{CO}_{2}(g) \\
& 2 \mathrm{SiO}(g)+\mathrm{CO}(g)+\mathrm{N}_{2}(g) \rightarrow \mathrm{Si}_{2} \mathrm{~N}_{2} \mathrm{O}(s)+\mathrm{CO}_{2}(g)
\end{aligned}
$$

Therefore, the partial pressure of $\mathrm{SiO}$ in the gas phase is closely related to phase stability and materials processing.

The $\mathrm{Si}_{3} \mathrm{~N}_{4} / \mathrm{Si}_{2} \mathrm{~N}_{2} \mathrm{O} / \mathrm{SiC}$ and $\mathrm{SiO}_{2} / \mathrm{Si}_{2} \mathrm{~N}_{2} \mathrm{O} / \mathrm{SiC}$ or $\mathrm{Si}_{3} \mathrm{~N}_{4} /$ $\mathrm{Si}_{2} \mathrm{~N}_{2} \mathrm{O} / \mathrm{Si}$ and $\mathrm{SiO}_{2} / \mathrm{Si}_{2} \mathrm{~N}_{2} \mathrm{O} / \mathrm{Si}$ equilibria are shown in Fig. 7 as a function of $\mathrm{SiO}$ partial pressure and temperature. The $\mathrm{SiO}$ pressure in the gas phase in equilibrium with $\mathrm{Si}_{3} \mathrm{~N}_{4} / \mathrm{Si}_{2} \mathrm{~N}_{2} \mathrm{O} / \mathrm{SiC}$ is

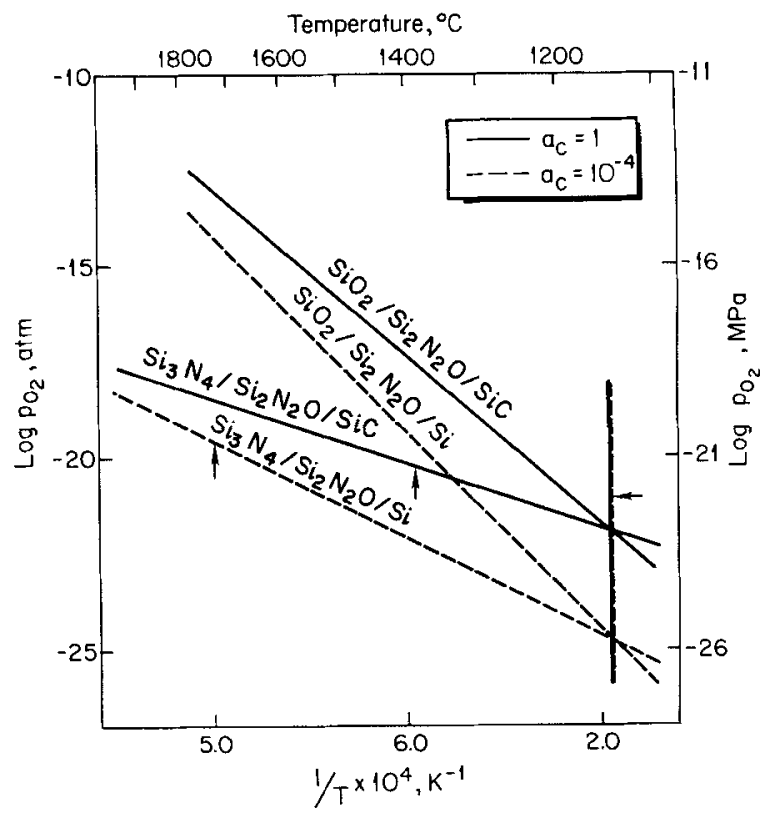

Fig. 5. Changes in equilibrium oxygen partial pressure at invariant points as a function of temperature at $a_{\mathrm{C}}=1$ and $10^{-4}$

relatively low - approximately $10^{-5}$ atm $\left(10^{-6} \mathrm{MPa}\right)$ at $a_{\mathrm{C}}=$ 1 - and increases 1 order of magnitude with the reduction of carbon activity to $10^{-4}$. This increase in $p_{S i O}$ is less with increased nitrogen pressure. This implies that the decomposition of $\mathrm{Si}_{3} \mathrm{~N}_{4}$ by a graphite crucible can be reduced by increasing nitrogen pressure and keeping the $\mathrm{SiO}$ gas in the crucible by packing it with auxiliary $\mathrm{Si}_{3} \mathrm{~N}_{4}$ powders.

\section{(5) Application as a Guideline}

Densification of ceramic powders or composites by solid-phase sintering is a complicated process which involves powder preparation, green compact preparation, and sintering. There has been considerable active research on the parameters in these processes, such as, sintering temperatures, powder sizes, and compositions. Since the gas phase of the sintering process is usually controlled by the flowing gas, the stability diagram is constructed as a function of temperature for known nitrogen pressures and carbon activities. Flowing nitrogen gas is commonly used for silicon

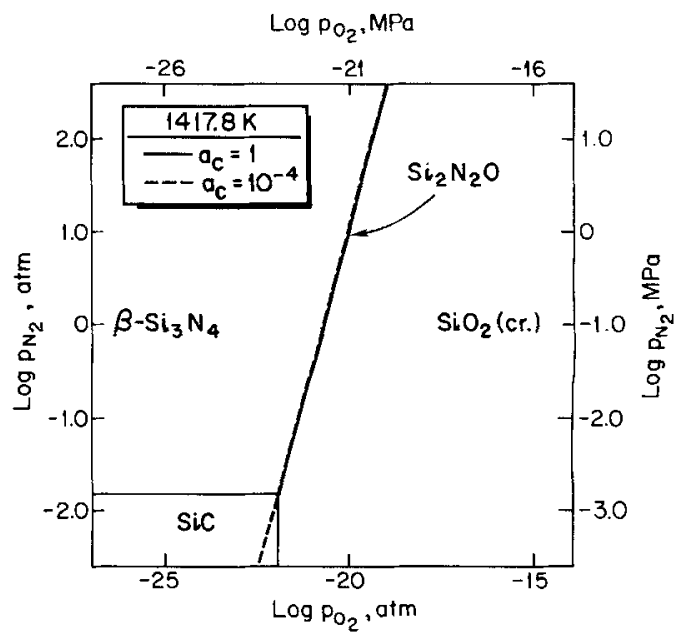

Fig. 6. Phase stability diagram as a function of partial pressures of nitrogen and oxygen at $T=1417.8 \mathrm{~K}$ and $a_{\mathrm{C}}=1$ and $10^{-4}$. 


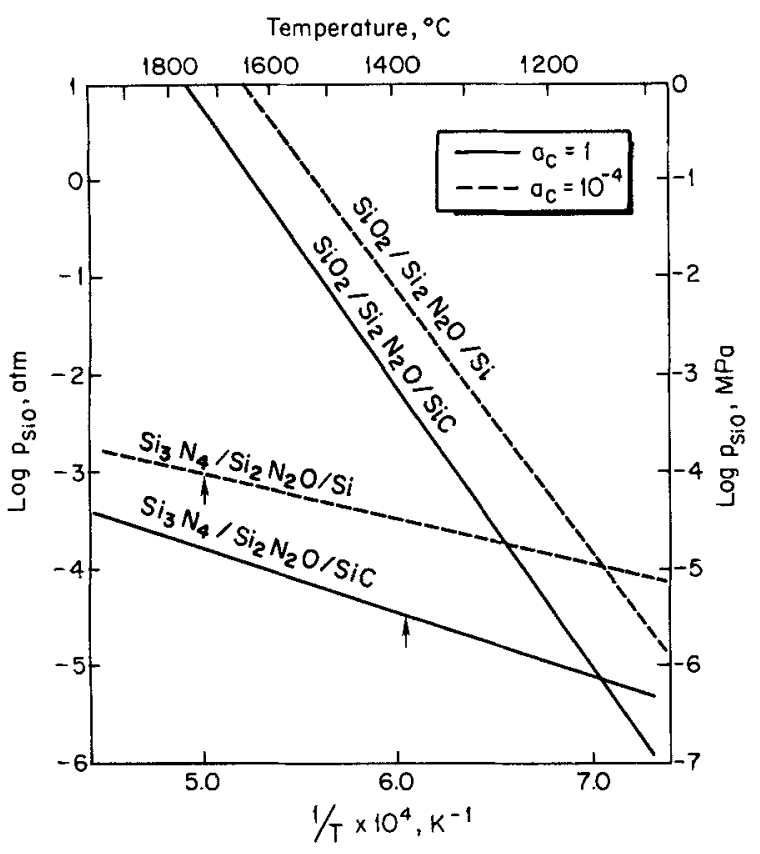

Fig. 7. Changes in equilibrium SiO partial pressure at invariant points as a function of temperature at $a_{\mathrm{C}}=1$ and $10^{-4}$.

nitride sintering. Typical results are shown in Figs. 8 and 9. These results, combined with gas compositions, can be applied as a guideline to sintering both $\mathrm{Si}_{3} \mathrm{~N}_{4}$ and $\mathrm{SiC} / \mathrm{Si}_{3} \mathrm{~N}_{4}$ composite.

Figure 8 shows that for a nitrogen pressure of 1 atm $(0.10 \mathrm{MPa}), \mathrm{Si}_{3} \mathrm{~N}_{4}$ cannot be sintered without forming $\beta$-SiC at temperatures higher than $1374^{\circ} \mathrm{C}$, even if the oxygen pressure is kept below $10^{-20}$ atm $\left(10^{-21} \mathrm{MPa}\right)$. However, if the nitrogen pressure is increased to $10 \mathrm{~atm}(1.01 \mathrm{MPa})$, the sintering temperature of $\mathrm{Si}_{3} \mathrm{~N}_{4}$ increases to $1536^{\circ} \mathrm{C}$ without $\mathrm{SiC}$ formation. Furthermore, using a BN crucible instead of a graphite crucible for sintering would increase the possible sintering temperature to more than $1800^{\circ} \mathrm{C}$ (Fig. 9). For the sintering of $\mathrm{Si}_{3} \mathrm{~N}_{4}$, at each level of carbon activity, the nitrogen pressure must be always higher than the $\mathrm{Si}_{3} \mathrm{~N}_{4} / \mathrm{Si}_{2} \mathrm{~N}_{2} \mathrm{O} / \mathrm{SiC}$ line in Fig. 4, whereas the oxygen pressure must be lower than the $\mathrm{Si}_{3} \mathrm{~N}_{4} / \mathrm{Si}_{2} \mathrm{~N}_{2} \mathrm{O} / \mathrm{SiC}$ line in Fig. 5. If a carbon container is used for sintering $\mathrm{Si}_{3} \mathrm{~N}_{4}$ at $1700^{\circ} \mathrm{C}$, nitrogen pressure as high as $70 \mathrm{~atm}(7 \mathrm{MPa})$ is required. Appropriate nitrogen pressures are much higher at higher temperatures. If the activity of carbon is reduced to $a_{\mathrm{C}}=10^{-4}$, however, $\mathrm{Si}_{3} \mathrm{~N}_{4}$ can be sintered with atmospheric nitrogen pressure at $1700^{\circ} \mathrm{C}$.

On the other hand, the $\mathrm{SiC} / \mathrm{Si}_{3} \mathrm{~N}_{4}$ matrix composite should be sintered at conditions for which the two phases coexist. Therefore, the carbon activity, the nitrogen pressure, and the gas phase should be well controlled. For instance, $\mathrm{Si}_{3} \mathrm{~N}_{4}$ and $\mathrm{SiC}$ are in equilibrium at $p_{\mathrm{N}_{2}}=1.48 \mathrm{~atm}(0.15 \mathrm{MPa})$ and $p_{\mathrm{O}_{2}}<7.41 \times 10^{-21}$ atm $\left(7.59 \times 10^{-22} \mathrm{MPa}\right)$ at $1673 \mathrm{~K}$ when a graphite crucible is used, whereas the equilibrium conditions change to $p_{\mathrm{N}_{2}}=70.79 \mathrm{~atm}(7.24 \mathrm{MPa})$ and $p_{\mathrm{O}_{2}}<2.40 \times 10^{-19}$ atm $\left(2.45 \times 10^{-20} \mathrm{MPa}\right)$ at $1973 \mathrm{~K}$ (Fig. 2). Nitrogen pressure must be increased almost 50 times with an increase of $300^{\circ} \mathrm{C}$ in the sintering temperatures. If the nitrogen pressure is lower than the values at $\mathrm{SiC} / \mathrm{Si}_{3} \mathrm{~N}_{4}$ equilibrium, the $\mathrm{SiC}$ phase becomes more stable and the $\mathrm{Si}_{3} \mathrm{~N}_{4}$ matrix would be deteriorated. When the composite is sintered in a graphite crucible under $1 \mathrm{~atm}(0.10 \mathrm{MPa})$ of nitrogen gas flow, the sintering temperature should be close to $1374^{\circ} \mathrm{C}$, whereas it can be increased to $1536^{\circ} \mathrm{C}$ when sintering is conducted at a high nitrogen pressure of $10 \mathrm{~atm}(1.01 \mathrm{MPa})$.

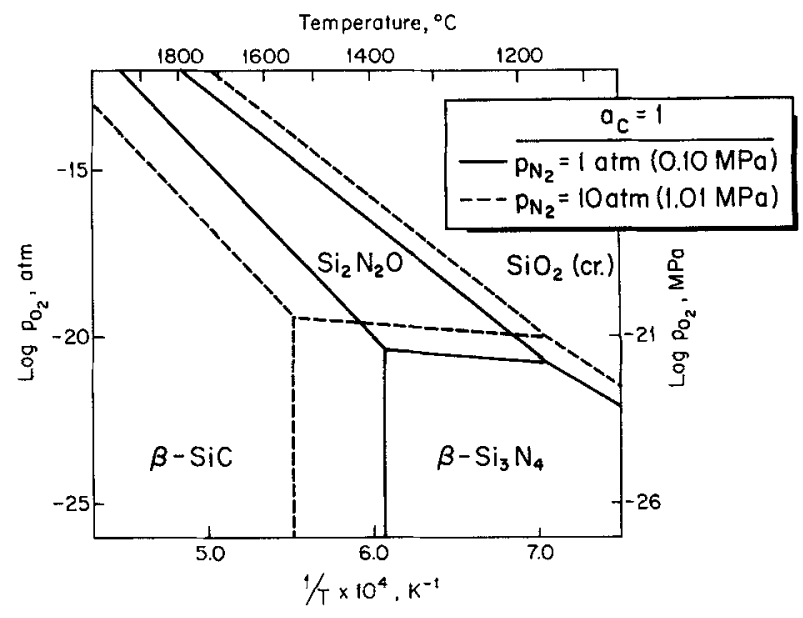

Fig. 8. Phase relationships in the Si-C-N-O system as a function of oxygen partial pressure and temperature at $a_{\mathrm{C}}=1, p_{\mathrm{N}_{2}}=1 \mathrm{~atm}$ $(0.10 \mathrm{MPa})$, and $p_{\mathrm{N}_{2}}=10 \mathrm{~atm}(1.01 \mathrm{MPa})$.

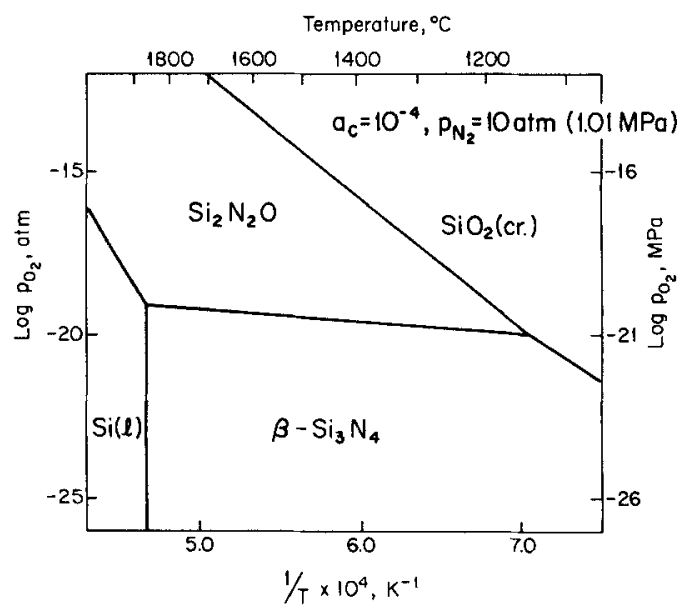

Fig. 9. Phase relationships in the $\mathrm{Si}-\mathrm{C}-\mathrm{N}-\mathrm{O}$ system as a function of oxygen partial pressure and temperature at $a_{\mathrm{C}}=10^{-4}$ and $p_{\mathrm{N}_{2}}=10 \mathrm{~atm}(1.01 \mathrm{MPa})$.

Reducing carbon activity would allow an increase in the sintering temperature. However, reducing the carbon activity too much would introduce metallic Si formation and increase the possibility of $\mathrm{SiO}_{2}$ phase formation. If the carbon activity is reduced as low as $a_{\mathrm{C}}=10^{-4}$, the $\mathrm{SiC}$ phase will deteriorate and the metallic $\mathrm{Si}$ phase will be formed in a composite sintered at $1870^{\circ} \mathrm{C}$, even when the nitrogen pressure is $10 \mathrm{~atm}(1.01 \mathrm{MPa})$.

\section{References}

'J. Weiss, H. L. Lukas, J. Lorenz, G. Petzow, and H. Krieg, "Calculation of Heterogeneous Phase Equilibria in Oxide-Nitride Systems," CALPHAD: Comput. Coupling Phase Diagrams Thermochem., 5 [2] 125-40 (1981).

$2 \mathrm{f}$. Weiss, H. L. Lukas, and G. Petzow, "Calculation of Phase Equilibria in Systems Based on $\mathrm{Si}_{3} \mathrm{~N}_{4}$ "; pp. $77-87$ in Progress in Nitrogen Ceramics. Edited by F. L. Riley. Martinus Nijhoff, The Hague, Netherlands, 1983.

${ }^{3}$ E. -Th. Henig, H. L. Lukas, and G. Petzow, CALPHAD VII Meeting, Stuttgart, FRG, April 1978, extended abstract pp. 235-44, 1978.

${ }^{4} \mathrm{G}$. Eriksson, "Thermodynamic Studies of High-Temperature Equilibria," Chem. Scr., 8, 100-103 (1975).

${ }^{5}$ JANAF Thermochemical Tables, 3d ed., American Chemical Society and American Institute of Physics for National Bureau of Standards, 1986.

${ }^{6} \mathrm{~A}$. Hendry, "Thermodynamics of Silicon Nitride and Oxynitride"; pp. 183-84 in Nitrogen Ceramics. Edited by F. L. Riley. Noordhoff International, Leyden, Netherlands, 1977 